\title{
'Nightfall' Thornless Trailing Blackberry
}

\author{
Chad E. Finn
}

U.S. Department of Agriculture-Agricultural Research Service, Horticultural Crops Research Laboratory, Northwest Center for Small Fruit Research, Corvallis, OR 97330

Brian M. Yorgey

Department of Food Science, Oregon State University, Corvallis, OR 97331

Bernadine C. Strik

Department of Horticulture, Oregon State University, Corvallis, OR 97331

\section{Robert R. Martin}

U.S. Department of Agriculture, Agricultural Research Service, Horticultural Crops Research Laboratory, Northwest Center for Small Fruit Research, Corvallis, OR 97330

Additional index words. Rubus, fruit breeding, spineless, processing

'Marion' is currently the most important blackberry (Rubus L. subgenus Rubus) cultivar in the world and it is the predominant cultivar grown for the processed fruit market (Finn et al., 1997). While 'Marion' produces fruit of outstanding quality for processing, the plants are thorny (botanically termed spiny). When 'Marion' is machine harvested, thorns can end up in the product (Strik and Buller, 2002), which can lead to a poor product, and, more significant in an economic sense, lawsuits. As a result, a primary priority for the breeding program has been the development of cultivars that are thornless, machine harvestable, and retain the excellent processing characteristics of 'Marion'.Three thornless blackberry cultivars with these qualities are being released simultaneously: 'Nightfall', 'Black Diamond' (Finn et al., 2005a), and 'Black Pearl' (Finn et al., 2005b).

'Nightfall' is a thornless trailing blackberry from the U.S. Department of AgricultureAgricultural Research Service (USDA-ARS) breeding program in Corvallis, Ore., released in cooperation with the Oregon State University Agricultural Experiment Station and the Washington State University Agricultural Research Center. 'Nightfall' has yields and fruit quality similar to 'Marion'. The plants are thornless and adapted to machine harvesting.

\section{Origin}

In 1996, 'Nightfall' was selected in Corvallis from a 1993 cross of 'Marion' $\times$ 'Waldo', and tested as ORUS 1486-2. 'Marion's importance

Received for publication 8 June 2005. Accepted for publication 18 Aug. 2005. This research was partially funded by the Oregon Raspberry and Blackberry Commission and the Northwest Center for Small Fruit Research. We gratefully acknowledge the assistance of Mary Peterson, Connie Pace, and Gloria Murray in 'Nightfall's evaluation; Nola Mosier for providing and maintaining clean nuclear stock; and Derek Peacock, formerly of Enfield Farms (Lynden, Wash.), for trial results.
Research and Extension Center (NWREC) Aurora, Ore. In each of the trial plantings, standard cultural practices for trailing blackberry production were used, including annual pre- and postemergent herbicide applications, annual spring nitrogen fertilization $(78 \mathrm{~kg} \mathrm{~N} /$ ha), postharvest removal of floricanes, training of primocanes to a two wire trellis, and weekly overhead application of about $2.5 \mathrm{~cm}$ of irrigation. All plantings received applications of dormant season fungicides (liquid lime sulfur and copper hydroxide) to control leaf and cane spot (Septoria rubi Westend.), purple blotch [Septocyta ruborum (Lib.) Petr.], rust [Kuehneola uredinis (Link) Arth.] and anthracnose [Elsinoe veneta (Burkholder) Jenk.]. They also received a single bloom application of captan to control anthracnose, botrytis (Botrytis cinerea Pers.: Fr.), cane spot, purple blotch and stamen blight (Hapalosphaeria deformans [Syd.] Syd.) at labeled rates. The replicated planting at NWREC was arranged in a randomized complete block design, with four, three-plant replications used for fresh fruit characteristics and three replications hand harvested once per week to determine harvest season, yield and fruit weight. The average fruit weight for a season is a weighted mean based on the weight of a randomly selected subsample of 25 fruit from each harvest. These data, collected from 2001-03, were analyzed as a split plot in time with cultivar as the main plot and year as the subplot. Of the 23 genotypes harvested in replicated trial for yield, only the data from 'Marion', 'Silvan', 'Siskiyou', and 'Waldo' and the new releases 'Nightfall', 'Black Diamond' (Finn et al., 2005a), and 'Black Pearl' (Finn et al, 2005b) were included in the analysis (PROC GLM; SAS Institute, Cary, N.C.). The cultivar $\times$ year interaction was significant for yield but not for fruit weight. Therefore, the interaction means for yield are presented and compared using Duncan's multiple range test (Table 1). The fruit ripening season in Oregon was characterized by the dates at which $5 \%$, $50 \%$, and $95 \%$ of the total fruit yield were harvested (Table 2). In 2001, 'Nightfall' was planted, along with a number of genotypes, in plots at Enfield Farms (Lynden, Wash.) along the Canada-U.S. border to assess cold hardiness and suitability for machine harvest. While observations were made on these plants from 2002-04, the winters were relatively mild (minimum winter temperature in Winter 2001-02 was $-8.0^{\circ} \mathrm{C}$ with -3.8 and $-9.7^{\circ} \mathrm{C}$ minimums in the following two winters). In
'Nightfall' has been tested predominantly at the Oregon State University North Willamette
Table 1. Fruit weight and yield in 2001-03 for blackberry genotypes planted in 1999 in replicated trial at the Oregon State University-North Willamette Research and Extension Center in Aurora.

\begin{tabular}{|c|c|c|c|c|c|}
\hline \multirow[b]{3}{*}{ Genotype } & \multirow{3}{*}{$\begin{array}{c}\begin{array}{c}\text { Fruit } \\
\text { size }(\mathrm{g})^{\mathrm{z}}\end{array} \\
2001-03\end{array}$} & \multicolumn{4}{|c|}{ Yield $\left(\mathrm{kg} \cdot \mathrm{ha}^{-1}\right)$} \\
\hline & & & & & Mean \\
\hline & & 2001 & 2002 & 2003 & $2001-03$ \\
\hline Nightfall & $6.2 \mathrm{~b}$ & $42447 \mathrm{a}$ & $13405 \mathrm{a}$ & $20962 \mathrm{a}$ & $25604 \mathrm{a}$ \\
\hline Silvan & $6.2 \mathrm{bc}$ & $31757 \mathrm{ab}$ & $16811 \mathrm{a}$ & $21485 \mathrm{a}$ & $23351 \mathrm{a}$ \\
\hline Black Diamond & $5.8 \mathrm{~cd}$ & $29281 \mathrm{a}-\mathrm{c}$ & $15568 \mathrm{a}$ & $19001 \mathrm{a}$ & $21283 \mathrm{ab}$ \\
\hline Marion & $5.1 \mathrm{e}$ & $26380 \mathrm{a}-\mathrm{c}$ & $13021 \mathrm{a}$ & $18397 \mathrm{a}$ & $19266 \mathrm{ab}$ \\
\hline Black Pearl & $6.2 \mathrm{~b}$ & $26969 a-c$ & $14373 \mathrm{a}$ & $15505 \mathrm{ab}$ & $18949 \mathrm{ab}$ \\
\hline Waldo & $5.5 \mathrm{~d}$ & $25849 \mathrm{bc}$ & $11000 \mathrm{a}$ & $17286 \mathrm{a}$ & $18045 \mathrm{ab}$ \\
\hline Siskiyou & $6.9 \mathrm{a}$ & $20969 \mathrm{c}$ & $9854 \mathrm{a}$ & $9359 \mathrm{~b}$ & $13394 \mathrm{~b}$ \\
\hline
\end{tabular}

${ }^{\mathrm{z}}$ Means withing a column followed by the same letter are not significantly different $p>0.05$, by Duncan's multiple range test. 
2003, fruit were harvested by an over-the-row (Littau, Stayton, Ore.) harvester with a horizontal (Christy) head from five-plant plots (Table 3). Subjective fruit evaluations were made during the fruiting season using a 1 to 9 scale ( $9=$ the best expression of each trait). These subjective evaluations were done on cultivars in the replicated trial as well as important commercial cultivars ('Chester Thornless' and 'Kotata') that were not. The fruit ratings included firmness (as measured subjectively by hand in the field on six to eight berries), color, shape (with a uniform, long conic ideal), texture (as measured subjectively when chewed while tasting berries in the field), separation (subjective rating of how easily ripe fruit separated from the plant), and flavor (subjectively rated by tasting berries in the field) (Table 4). Plant ratings were conducted one time each year from 2001-03 during the fruiting season for primocane and floricane vigor, spines $(9$ = spineless; cultivars derived from 'Austin Thornless' are seldom completely spineless, basal spines are common and occasionally a single spine on the lower side of the petiolule), and flowering/fruiting lateral length (1 $=$ very short, $5=$ very long $)$ and strength $(1=$ weak, droopy; 5 = stiff, sturdy) (Table 4). In a concurrent study, Yorgey and Finn (2005) evaluated the processing characteristics of several cultivars and advanced selections in- cluding 'Nightfall'. They prepared individually quick frozen and puree products from several genotypes for evaluation by a blind panel of untrained experts.

In Oregon, 'Nightfall' had a similar yield to 'Marion', 'Silvan', and 'Waldo' but a greater yield than 'Siskiyou' in each year except 2002 (Table 1). 'Nightfall' tended to have a higher yield than 'Marion' and 'Waldo' in all years. In the machine harvested Washington State trial, 'Nightfall' was the second highest yielding genotype (Table 3 ) and the fruit harvested well with few defective (i.e., green, pedicels still on) fruit. Fruit size for 'Nightfall' tends to be larger than 'Marion' or 'Waldo', very similar to 'Silvan' but not as large as 'Siskiyou' (Table 1).

'Nightfall' harvest begins the first few days of July, peaks in early July and is largely done by the third week of July in Oregon (Table 2). The harvest season is almost identical to 'Marion', later ripening than 'Obsidian' and 'Metolius' and earlier than 'Waldo'. In Washington, while the beginning and end of the harvest season were very similar to 'Marion', the peak of harvest was a few days later, more similar to 'Boysen' (Table 3).

Fruit of 'Nightfall' are usually conic, more uniformly shaped than 'Marion' but not as uniform as 'Waldo' (Table 4, Fig. 1). 'Nightfall' fruit are firmer than 'Marion' and 'Silvan'

Table 2. Mean ripening season and date at which yield of each genotype reached the given percentage of total yield at the Oregon State University-North Willamette Research and Extension Center in Aurora. Trial was planted in 1999 and harvested in 2001-03.

\begin{tabular}{lccc}
\hline & \multicolumn{3}{c}{ Harvest season } \\
\cline { 2 - 4 } Genotype & $5 \%$ & $50 \%$ & $95 \%$ \\
\hline Metolius & 25 June & 3 July & 14 July \\
Obsidian & 25 June & 4 July & 15 July \\
Siskiyou & 25 June & 8 July & 25 July \\
Silvan & 26 June & 8 July & 21 July \\
Black Diamond & 28 June & July & 21 July \\
Marion & 3 July & 10 July & 22 July \\
Black Pearl & 3 July & 11 July & 24 July \\
Nightfall & 3 July & 22 July & 23 July \\
Waldo & 8 July & 7 Aug. \\
\hline
\end{tabular}

Table 3. Yield and harvest season for blackberry genotypes planted in one or two five-plant plots (1.4 m plant spacing) in 2001 and 2002 at Enfield Farms (Lynden, Wash.). Plants were primarily harvested with an over the row harvester (Littau, Stayton, Ore) with a horizontal (Christy) head.

\begin{tabular}{|c|c|c|c|c|c|}
\hline \multirow[b]{2}{*}{ Genotype } & \multirow{2}{*}{$\begin{array}{c}\text { Yield } \\
\left(\mathrm{kg} \cdot \mathrm{ha}^{-1}\right)\end{array}$} & \multicolumn{3}{|c|}{2003 Harvest season } & \multirow{2}{*}{$\begin{array}{l}\text { No. } \\
\text { plots }\end{array}$} \\
\hline & & $5 \%$ & $50 \%$ & $95 \%$ & \\
\hline Black Diamond & 17281 & 11 July & 21 July & 6 Aug & 2 \\
\hline Nightfall & 14384 & 11 July & 25 July & 6 Aug. & 1 \\
\hline Silvan & 12106 & 11 July & 21 July & 3 Aug. & 2 \\
\hline Marion & 10382 & 11 July & 21 July & 6 Aug. & 2 \\
\hline Siskiyou & 9656 & 11 July & 21 July & 31 July & 1 \\
\hline Boysen & 8670 & 16 July & 25 July & 31 July & 1 \\
\hline Metolius & 8480 & 11 July & 11 July & 25 July & 1 \\
\hline Waldo & 7112 & 21 July & 31 July & 6 Aug. & 2 \\
\hline
\end{tabular}

Table 4. Mean scores for subjectively evaluated characteristics ${ }^{\mathrm{z}}$ of 'Nightfall' and three commercial blackberry cultivars planted in 1999 at the Oregon State University-North Willamette Research and Extension Center in Aurora.

\begin{tabular}{|c|c|c|c|c|c|c|c|c|c|c|c|}
\hline \multirow[b]{2}{*}{ Cultivar } & \multirow{2}{*}{$\begin{array}{c}\text { Primocane } \\
\text { vigor }\end{array}$} & \multirow[b]{2}{*}{ Thorns } & \multirow{2}{*}{$\begin{array}{c}\text { Floricane } \\
\text { vigor }\end{array}$} & \multicolumn{2}{|c|}{ Fruiting lateral } & \multicolumn{6}{|c|}{ Fruit } \\
\hline & & & & Length & Strength & Firm & Color & Shape & Texture & Separation & Flavor \\
\hline Nightfall & 9.0 & 8.3 & 8.3 & 4.3 & 2.5 & 7.2 & 8.0 & 8.2 & 8.3 & 8.2 & 7.0 \\
\hline Marion & 9.0 & 4.6 & 8.5 & 4.8 & 3.3 & 5.4 & 8.3 & 6.7 & 8.9 & 8.9 & 8.6 \\
\hline Silvan & 9.0 & 3.1 & 7.9 & 3.5 & 2.7 & 3.9 & 7.1 & 7.2 & 8.2 & 8.6 & 8.0 \\
\hline Waldo & 8.6 & 8.4 & 7.6 & 1.7 & 4.5 & 7.0 & 8.6 & 8.9 & 8.8 & 8.8 & 6.9 \\
\hline
\end{tabular}

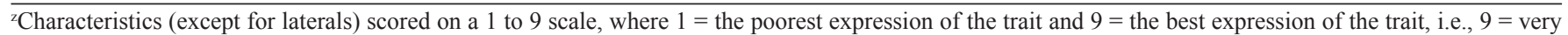

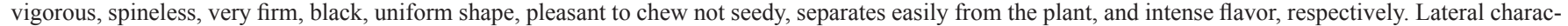
teristics scored on a 1 to 5 scale, where $1=$ short or weak laterals and $5=$ long or strong laterals. 


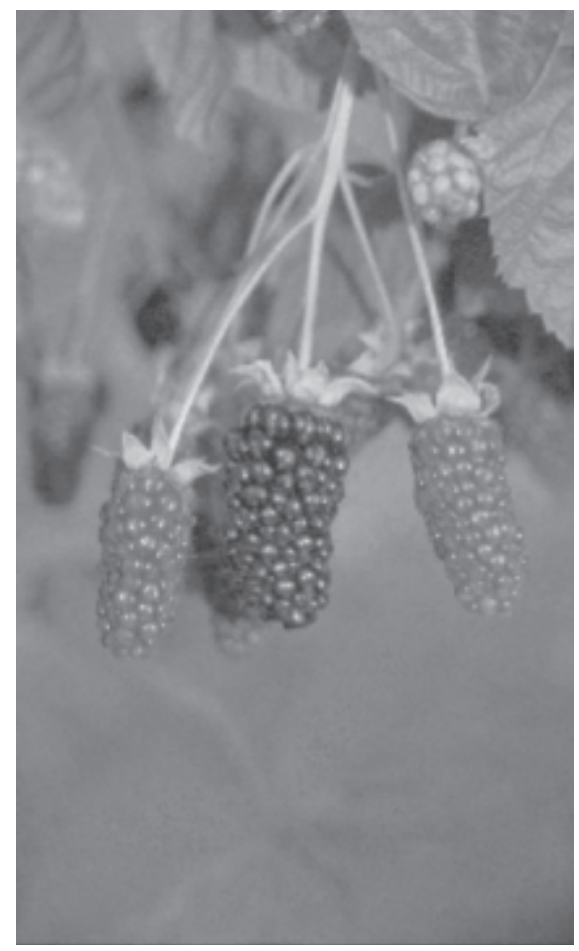

Fig. 1.'Nightfall' (a) fruiting lateral and (b) plant.

2001-02 and 2002-03 winters. In Fall 2003, the temperatures dropped rapidly to -3 to -6 ${ }^{\circ} \mathrm{C}$ in Oregon and -4 to $-8{ }^{\circ} \mathrm{C}$ in northern Washington during the last $2 \mathrm{~d}$ of October. Many genotypes including 'Marion' and 'Silvan', as well as 'Nightfall', were severely damaged (cane and bud death) by this rapid change in temperatures in our Washington, but not our Oregon, trials. One reason for the greater damage in Washington may be that the plots were in a commercial red raspberry field where plants were heavily fertilized with nitrogen and irrigated to maximize growth the first year and yield the following year. This approach may have led to injury on plants that

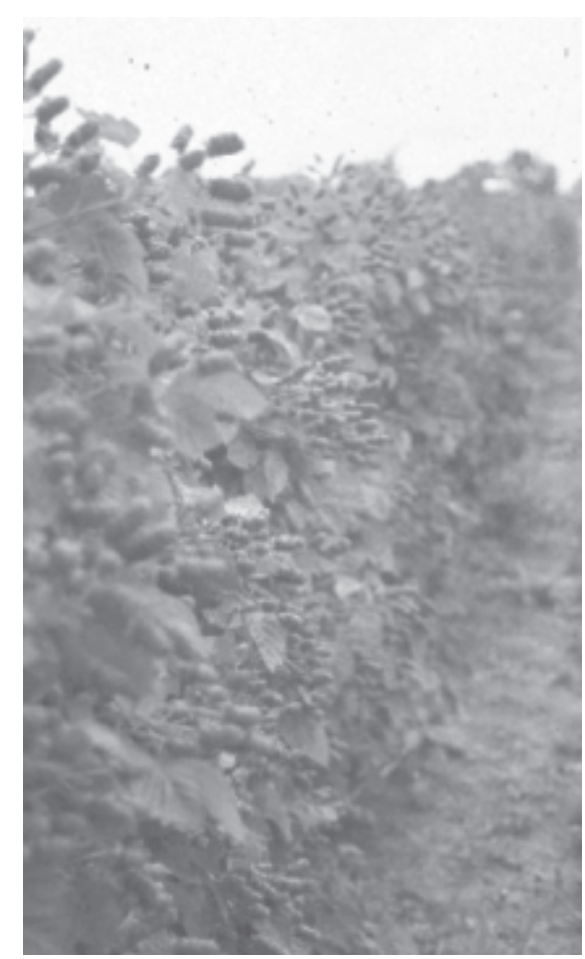

were not yet dormant. 'Nightfall' appears to be similar to its parent 'Marion' in adaptation to cold temperatures.

Outstanding characteristics of 'Nightfall' include large fruit, a yield similar to that of 'Marion', good processed fruit quality, excellent adaptation to machine harvesting, and thornless plants with good disease tolerance. 'Nightfall' should be a useful commercial cultivar for the processed blackberry industry. 'Nightfall' will not likely be well suited for the fresh market as it is too tart and lacks sufficient firmness to be shipped as a fresh fruit. 'Nightfall' is expected to perform well in areas where trailing blackberries are adapted, including the Pacific Northwest, California, Chile, New Zealand, United Kingdom, and the Mediterranean region.

\section{Availability}

'Nightfall' is not patented. When this germplasm contributes to the development of a new cultivar or germplasm, the authors request that appropriate recognition be given to the source. 'Nightfall' nuclear stock has tested negative for tomato ringspot, raspberry bushy dwarf, and tobacco streak viruses by ELISA and has indexed negative on grafting to $R$. occidentalis. Further information or a list of nurseries propagating 'Nightfall' is available on written request to the contact author. The USDA-ARS does not have commercial quantities of plants to distribute. In addition, plants of 'Nightfall' have been deposited in the National Plant Germplasm System, at USDA-ARS NCGR in Corvallis, Ore. accession number PI 638263, where it is available for research purposes, including development and commercialization of new cultivars.

\section{Literature cited}

Finn, C.E., B.M. Yorgey, B.C. Strik, R.R. Martin, and M.C. Qian. 2005b. 'Black Pearl'thornless trailing blackberry. HortScience 40:2179-2181.

Finn, C.E., B.M. Yorgey, B.C. Strik, R.R. Martin, and M.C. Qian. 2005a. 'Nightfall' thornless trailing blackberry. HortScience 40:2182-2184.

Finn, C., B.C. Strik, and F.J. Lawrence. 1997. Marion trailing blackberry. Fruit Var. J. 51:130-132.

Meng, R. and C. Finn. 2002. Determining ploidy level and nuclear DNA content in Rubus by flow cytometry. J. Amer. Soc. Hort. Sci. 127:767-775.

Strik, B. and G. Buller. 2002. Reducing thorn contamination in machine-harvested 'Marion' blackberry. Acta Hort. 585:677-681.

Thompson, M.M. 1995. Chromosome numbers of Rubus cultivars at the National Clonal Germplasm Repository. HortScience 30:1453-1456.

Yorgey, B.M. and C.E. Finn. 2005. Comparison of 'Marion' to thornless blackberry genotypes as individually quick frozen and puree products. HortScience 40:513-515. 